This a non-per reviewed manuscript. A subsequent version of this manuscript might have slightly different content.

\title{
Timing of oil expulsion from source rocks and a revitalization of the pre-1970 model
}

\author{
By \\ Per Arne Bjørkum
}

Equinor ASA, Norway, and Professor emeritus at University of Stavanger

email:pab@equinor.com

\begin{abstract}
New data from North Sea Upper Jurassic source rock samples show no decline in the total amount of organic matter (TOC) within the oil expulsion window between 120 and $150^{\circ} \mathrm{C}$ which is a key prediction by today's model for oil expulsion. However, today's model for oil expulsion is not consistent with either subsurface source rock TOC data or chemical attributes of shallow oils. Instead, these data are more consistent with oil expulsion occurring at much lower temperatures and shallower depths, more similar to models advocated by most oil explorers prior to 1970 where the oil was assumed to have expelled at burial depths less than $\sim 2 \mathrm{~km}$.

In this paper, main oil expulsion has been determined to be take place at burial depths less than $1 \mathrm{~km}$ and approximately $30^{\circ} \mathrm{C}$. The oil is mobilized by $\mathrm{CO}_{2}$ gas which is generated from decomposing organic matter and is predicted to migrate out of the source rock and into nearby high-permeable rocks via horizontal fractures that originate from loadbearing swelling organic lamina and in a direction towards decreasing overburden. The thermally
\end{abstract}


immature (heavy) oil is then converted to light crude within the reservoir oil starting at 60$70^{\circ} \mathrm{C}$ by hydrogenation. Hydrogen gas is common in subsurface fluids and is provided to pooled oil from coalification of organic matter in mudstones. Thus, if the supply of hydrogen is limited, in-reservoir thermal upgrading will be hampered. In this model, most of the heavy oil accumulations encountered are immature rather than due to biodegradation of mature oil at low temperatures.

\section{Introduction}

The problem of when, how, and where hydrocarbons are generated in sedimentary basins has been debated throughout most of the $20^{\text {th }}$ century. Prior to the 1970 's most geologists believed that oil was expelled from organic-rich mudstones early in their burial history in an immature state (Van Tuyl and Parker, 1947; Hedberg, 1964; Dott and Reynold, 1969), and that the resins and asphaltene non-hydrocarbons (NSOs) were converted to paraffinic hydrocarbons in reservoir rocks during burial (e.g., Banks, 1934; McNab et al., 1952). It was also believed that most hydrocarbons formed at temperatures well below $100^{\circ} \mathrm{C}$ (Hedberg, 1964).

Prior to the 1970's timing of oil expulsion from source rocks was based on observations made by field geologists who were involved in the discovery of most of the worlds giant oil fields, including most of the North American domestic accumulations (Wilson, 2005). It was recognized that traps which were formed early could contain oil while those formed later did not (Scholten, 1959; Banks, 1966). The oil was believed to migrate laterally into reservoirs from local source rocks (Van Tuyl and Parker, 1941; Gester, 1947; Hedberg, et al., 1947; Hedberg, 1964; Dott and Reynolds, 1969) which meant that early structuring and trap formation was considered critical (Hedberg, 1954; Weeks, 1958; Scholten, 1959; Banks 1966).

Early oil expulsion and the role of local source rocks was documented Hedberg et al. (1947) in their classical study of the shallow Tertiary Greater Oficina basins in Eastern Venezuela where oil in the individual lenticular sands varies in gravity, colour, gas content, wax content, sulphur, and other characteristics including gravities that range from less than $10^{\circ}$ to $57^{\circ} \mathrm{API}$. 
These differences could, according to Weeks (1956), only be explained by different source material for the oil.

Likewise, Teas and Miller (1933) concluded that in the Gutoskey lenticular sand zone, Raccoon Bend Filed of Texas expulsion was completed prior to $600 \mathrm{~m}$ of burial suggesting that the $14^{\circ}$ to $34^{\circ} \mathrm{API}$ oil variability (and other differences) was due to differences in local source rock material (see also Wilson (1990) for a review on early oil expulsion).

These early oil explorers were not able to develop a viable explanation for how viscous bituminous oil was transported out of source rocks and into reservoirs (Erdman, 1965; Hedberg 1964). In addition, artificial thermal maturation of these immature oils in laboratory experiments always led to the precipitation of significant amounts of (pyro)bitumen, which is normally not observed in reservoirs containing light oil (Connan et al., 1975; Rogers et al., 1974).

These two deficiencies in the pre-1970 model paved the way for a new and mainly laboratory-based (geo)chemical compromise model (Hunt, 1979) for in-source rock generation hydrocarbons, typically between 50 and $130^{\circ} \mathrm{C}$ and peaking at around $90^{\circ} \mathrm{C}$, from which today's model (Mackenzie and Quigley, 1988; Pepper and Corvie, 1995) was developed. Since the late 1980s, geochemists and geologists have assumed that in most sedimentary basins, hydrocarbons are generated within organic-rich mudstones at temperatures higher than $100^{\circ} \mathrm{C}$ and expelled in a mature and light state at temperatures ranging between 120 and $150^{\circ} \mathrm{C}$ (Mackenzie and Quigley, 1988). Heavy oil accumulations (Meyer et al. 2007) are generally thought to be the residue of these light oils where most of the paraffins with less than 30 carbon atoms have been removed by bacteria at reservoir temperatures less than $\sim 70^{\circ} \mathrm{C}$ (Evans et al., 1971; Milner et al., 1977; Head et al. 2003).

Today's model for generation and expulsion of oil is based on laboratory analysis. During high temperature $\left(>400^{\circ} \mathrm{C}\right)$, anhydrous pyrolysis of source rock samples 10 to $80 \%$ of the organic carbon is converted to hydrocarbons (Tissot et al., 1971; 1974; Ishiwatari et al., 1977; Quigley and Mackenzie, 1988; Baskin, 1997). While the Rock-Eval (Ishiwatari et al., 1977) results have been extensively compared between laboratories (Price and McNeil, 1997) the theoretical predictions have not been sufficiently corroborated with subsurface 
observations (e.g., Price and McNeil, 1997). Notably, it has not been shown that the total amount of organic carbon, TOC for short, decreases in source rocks as implied by the laboratory-based model (Peters and Cassa, 1994).

This paper highlights some subsurface observations that conflict with today's model. A TOC dataset from Norwegian North Sea marine (Type II) source rocks (Figure 1) and published data from pooled oil suggest that earlier models (e.g., Hedberg, 1964) better explain the observations compared to the established present-day model.

\section{Objections to today's model for generation and expulsion of oil}

Compilation of in-house data (Figure 1) shows TOC of 871 samples from the Upper Jurassic Draupne Formation source rock (Kimmeridge Clay Formation equivalent in the Norwegian North Sea) at burial depths of 3.5 to $4.5 \mathrm{~km}$. The median curve for TOC fluctuates around $5 \%$ throughout the whole interval and does not decline by some $50 \%$ within the predicted oil expulsion window (Okiongbo et al., 2005; Okiongbo, 2011). Previously published papers describing organic carbon content variation with depth in source rocks refer to North Sea data, though with only 13 samples, within the predicted oil expulsion window between 3.5 and $4.5 \mathrm{~km}$ burial depth (Okiongbo et al., 2005; Okiongbo, 2011) (this depth interval roughly corresponds to temperatures from 120 to $150^{\circ} \mathrm{C}$ ). The data from the predicted oil expulsion window presented by Okiongbo et al. (2005) and Okiongbo (2011) is too limited to be used to test the model but there is no reduction in TOC with depth which is consistent with the results presented in Figure 1. 


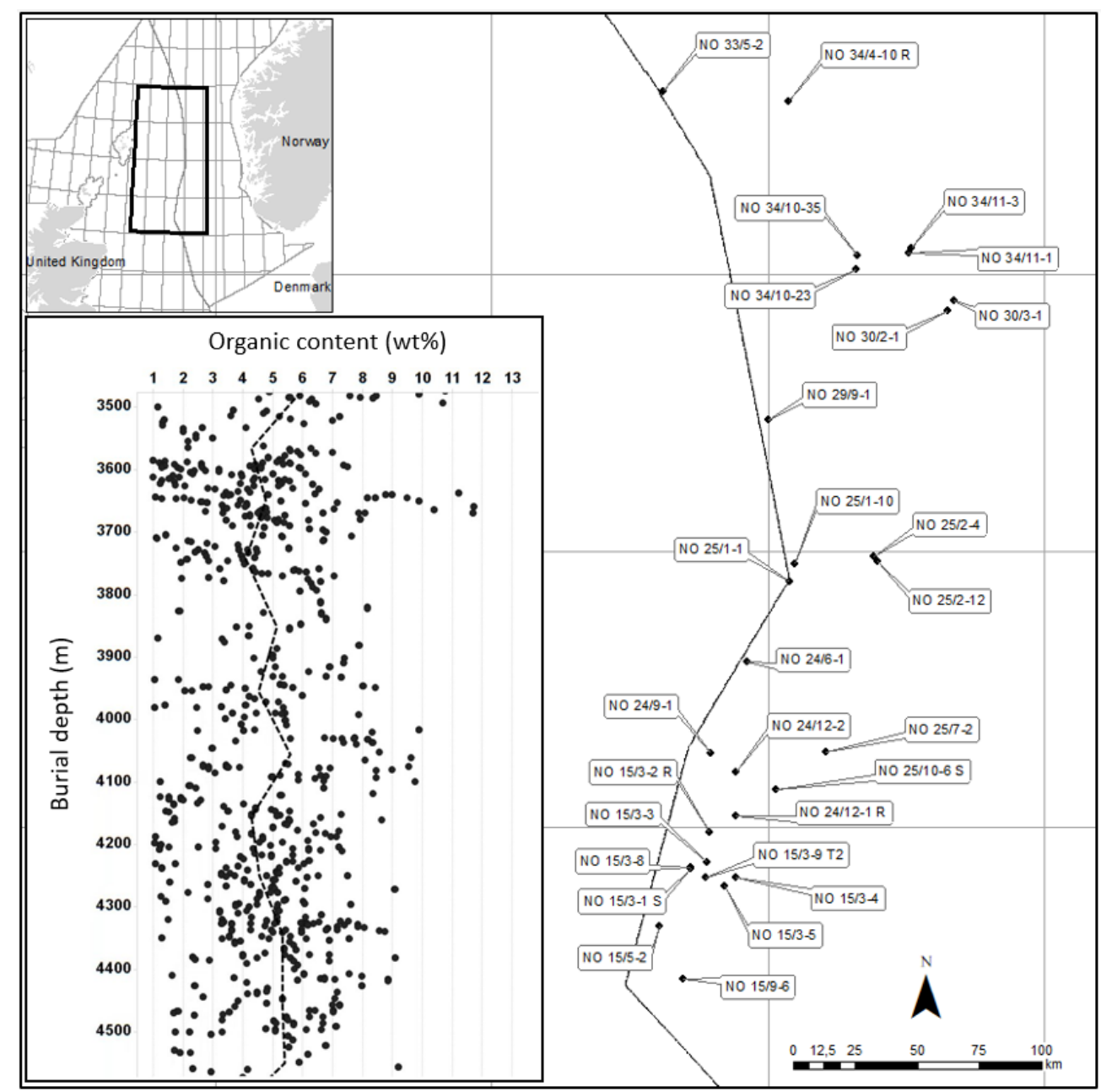

\section{Figure 1}

TOC of 871 source rock samples from 28 wells covering the predicted Draupne Formation oil expulsion window. Median (P50) TOC, calculated for every 100 metres, fluctuates around 5\% (stippled line). Samples with less than $1 \%$ TOC are defined as non-source rocks (Hunt, 1995) and are excluded from the plot. TOC is a measure of non-reactive organic matter + reactive organic matter + the $\mathrm{C}_{15+}$ (S1) fraction. In rock-eval pyrolysis $\left(\mathrm{T}>400^{\circ} \mathrm{C}\right)$ the reactive fraction ( $\left.\sim 50 \%\right)$ is converted to oil and most of it is predicted to be expelled from source rocks between 120 and $150^{\circ} \mathrm{C}$.

Hence, TOC data from North Sea source rocks conflict with the model prediction (Okiongbo et al. 2005; Okiongbo, 2011) for timing of oil expulsion which weakens the confidence in it, especially since samples from North Sea source rocks have been used in laboratory analysis to establish and justify the current model (Cooles et al.,1986; Pepper and Corvi, 1995; Hunt, 1995). 
Today's model can be upheld if the original TOC was higher and exactly compensated for the expelled organic carbon as suggested by Okiongbo et al. (2005) who wrote: "Total organic carbon ranges from $3.44 \%$ to $9.8 \%$, mainly between $4 \%$ and $9 \%$ (Table 1 ). Because petroleum generation and expulsion reduce the TOC content of oil-prone source rocks by around onehalf, the original TOC contents of the most mature samples would have been around 9-12\%" (p. 2497/2498). Although this is possible, it is considered extremely unlikely, especially due to the large number of TOC data presented in Figure 1.

Additionally, there are other chemical facts that appear to be incompatible with today's high-temperature expulsion model while being consistent with the pre-1970, such as:

a) The Athabasca heavy oil and bitumen in Western Canada are optically active (Montgomery et al, 1974; George et al., 1977) but the ability to rotate polarized light decreases with increasing thermal maturation and becomes close to zero at $65^{\circ} \mathrm{C}$ (Tissot and Welte, 1984). This suggests that a significant proportion of the oil must have been expelled from source rocks at temperatures well below $65^{\circ} \mathrm{C}$.

b) Many of the biomarkers (chemical "bio-fossils") used by organic geochemists to determine oil maturity (Farrimond et al., 1998) were discovered and calibrated during the 1970s and early 1980s when most geochemists believed that oil was expelled from source rocks at temperatures between 50 and $130^{\circ} \mathrm{C}$ (Hunt, 1979). The biomarkers from the 1970s and early 1980s are still in use (Hunt, 1995; Farrimond et al., 1998) even though oil is now predicted to be expelled from source rocks at temperature higher than $120^{\circ} \mathrm{C}$, that is, at temperatures where most of the biomarkers are useless (Tissot and Welte, 1984). Notably, $\beta \beta$-hopene, which is common in heavy oil and bitumen (Tissot and Welte, 1984), does not survive far into the catagenesis stage (Tissot and Welte, 1984 ), and temperatures higher than $50-70^{\circ} \mathrm{C}$, suggesting that fluids that contain $\beta \beta$ hopene cannot have experienced temperatures much higher than $70^{\circ} \mathrm{C}$.

c) Most oils with API less than $25^{\circ}$ are believed to be the remnants of in-reservoir bacterial degradation of lighter crude oils (e.g Hunt, 1995; Head et al. 2003; Nadeau et al., 2005). However, the presence of living microorganisms capable of degrading oil in subsurface reservoirs has never been documented (Head et al., 2003) and as such in-reservoir (subsurface) biodegradation should consequently be regarded as highly speculative. 
d) Bacteria are considered to operate at, or close to the oil water-contact, and to feed on nalkanes with less than $\sim 30$ carbons via molecular diffusion through the heavier asphaltene with oil that accumulates in the lower part of the column (Head et al., 2010). However, the physical model (Larter et al., 2003; Huang and Larter, 2005; Larter et al., 2006) ignores gravitational segregation due to buoyancy which would cause the lighter oil molecules to concentrate in the upper part of the column (Hirschberg, 1998). Also, electrical forces that cause the polar asphaltenes (concentrated at lower parts of the oil column) to repel the non-polar alkanes (Hirschberg, 1998) are ignored. Hence, the assumption that the biodegradation process itself produces substantially systematic compositional gradients in heavy oil fields (Larter et al., 2003) is not justified.

e) Light oil is shown to be converted to heavy oil by bacteria under laboratory conditions (Jobson et al., 1972). However, when these heavy, laboratory biodegraded oils are subsequently heated to temperatures higher than $400^{\circ} \mathrm{C}$, light paraffinic oil is not produced (Jobson et al., 1972; Hunt, 1979). Conversely, heavy oils found in reservoirs in nature generate light, crude-like oils upon high-temperature pyrolysis (Hunt, 1979; Cannon, 1974). This strongly suggests that the major heavy oil accumulations are in fact not biodegraded light oil, but rather oil that has never been heated to temperatures much above $70^{\circ} \mathrm{C}$.

f) According to Mayer et al. (2007) the average concentration of non-hydrocarbon asphaltenes and resins (NSOs) in light oil is 10.9\% (131 basins, 8148 accumulations) and increases to $35.6 \%$ (74 basins, 774 deposits) for heavy oil and $49.2 \%$ (50 basins, 305 deposits) for bitumen. If heavy oil is a residue where hydrocarbon molecules with less than $\sim 30$ carbon atoms have been eliminated by bacteria (Head et al., 2003) it means that the initial volume of oil should be reduced by 3 to 5 times in the transformation to heavy oil. Hence, unless oil is continuously supplied, a thick zone of residual oil below a current oil-water contact should be expected, but this is not commonly observed.

g) The average vanadium content in heavy oils and bitumen is more than ten times greater than in light oils (Meyer et al. 2007). Vanadium is present in a chlorophyll derivate (porphyrin) and cannot therefore be re-introduced to the oil after burial. As such, if the concentration of vanadium in heavy oils is due to selective removal of the light paraffins, the initial volume of oil must have been more than ten times larger; a statement which 
very unlikely (Meyer et a., 2007) since it would mean that some $90 \%$ of the expelled oil have been "eaten" (by unproven bacteria).

h) The average uranium content in bitumen is approximately $1000 \mathrm{ppb}$ which is about a thousand times more than in light oils with API between 30 and $40^{\circ}$ (Bell,1960). This suggests that bitumen cannot be the remains of degraded light oil (Bell, 1960) since uranium cannot be re-introduced to pooled oil by any known process.

i) Today's geochemical model for generation and expulsion of hydrocarbons rests on gas chromatography of heated rock samples where molecules with less than $\sim 40$ carbons evaporate (Ishiwatari et al., 1977; Hunt, 1995). The hetero-atomic (NSO) resin and asphaltene macromolecules, which makes up between 35,6 and $49.2 \%$ of heavy oil and bitumen respectively (Meyer et al., 2007) and more than $70 \%$ of the oil in organic matter down to $\sim 30 \mathrm{~m}$ below the seabed, typically have more than 40 carbons in their structure (Smith, 1952a,b; 1954). The asphaltenes in heavy oil or bitumen are reported to have a molecular weight of 1000-10,000amu (Hirschberg, 1988) which translates to between approximately 60 - 600 carbon atoms in the molecular structure and with alkanes having a molecular weight of 100-1000amu, that is $15-150$ carbon. However, the high-molecular weight $\mathrm{C}_{40+}$ non-hydrocarbons and hydrocarbons are not detected in standard gas chromatography of oil samples or pyrolysis of rock samples since they will not evaporate. Hence, the high-molecular oil fraction has been methodologically ignored since the invention of Rock-Eval pyrolysis and gas chromatography (Ishiwatari et al., 1977).

j) According to today's model, estimates for the proportion of expelled oil that ends up in accumulations is between $5 \%$ to $30 \%$ (Hunt, 1995). Most of the expelled oil is therefore assumed to be lost along the migration pathway from source to trap (England, 1994). Although wells might not be optimally positioned to detect migration route, we would expect to encounter permeable rock with residual oil saturation of $10-20 \%$ more often than we do (Wilson, 1990).

k) Van Tuyl and Parker (1941) stated that kerogen (organic matter) buried to depths greater than $2 \mathrm{~km}$ was unable to generate petroleum unless exposed to temperature well above those normally encountered at depths at which oil has been found in commercial quantities (p. 156). The statement was later supported by Hedberg (1964) who reported that the TOC has decreased significantly in the source rock close to thick magmatic 
intrusions.

The only chemical data that conflict with the pre-1970 model are those obtained under artificial high temperature laboratory conditions; thermal cracking of immature oil (Rogers et al., 1974; Evans et al., 1971; Connan et al., 1974; Hunt, 1979) and non-isothermal ( $\left.>400^{\circ} \mathrm{C}\right)$ Rock-Eval pyrolysis of source rock samples (Ishiwatari et al. 1977; Quigley and Mackenzie, 1988; Hunt,1995).

The use of non-isothermal Rock- Eval pyrolysis (Ishiwatari et al. 1977 ) was initially meant to be a screening tool for well-site geologists (Hunt, 1979). Its use for predicting purposes has been criticised because the fraction of hydrocarbons generated from non-isothermal RockEval pyrolysis varies as a function of sample size and heating rate (Dominé et al., 1988; Schneider, 1993; Price and McNeil, 1997). Schneider (1993) concluded that "in nonisothermal thermogravimetry the computed 'kinetic parameters' are valid for the weight loss in the used conditions only and they are neither related to the reaction mechanism, nor can they be used for predicting the course of the reaction in other conditions" (p.686) and that "From the point of view of chemical kinetics they are neither attributable to a determined reaction mechanism nor can they be used for predictions" (abstract).

However, Thermal breakdown of organic matter in close contact with magmatic intrusions (k) has been confirmed in recent publication (Moneral et al., 2009; Spacapan et al. (2018). Spacapan et al. (2018) showed that TOC is reduced by more than $50 \%$ in the Vaca Muerta marine (Type II) source rock in the immediate vicinity of intrusions which is the same reduction in TOC typically observed in Rock-Eval pyrolysis of marine source rock suggesting that Rock-Eval pyrolysis is merely replicating what happens under extreme condition in nature which substantiate the conclusion by Van Tuyl and Parker (1941) and Hedberg (1964).

The pre-1970 model was eventually abandoned because a viable physical explanation for early oil expulsion and a chemical model for in-reservoir generation of hydrocarbons was not found. In the following section, solutions to both these issues are proposed and the implications are addressed. 


\section{$\mathrm{CO}_{2}$ gas driven expulsion of bituminous oil from source rocks}

The main difficulty in explaining early oil expulsion stems mainly from the belief that both heavy oil (API ${ }^{\circ}$ between 10 and 25$)$ and extra heavy oil/bitumen $\left(A P I^{\circ}<10\right)$ had been transported out of organic-rich source rocks and into adjacent reservoirs in a physical state close to its present (Erdmann, 1965). It was considered impossible since it meant that oil was expelled with a viscosity 10-10.000 times greater than the average viscosity of conventional crude oil (Meyer et al., 2007). However, today's viscosity of pooled oil is not likely to be representative for the physical state during expulsion and immediately after pooling since the viscosity of the expelling oil is likely to be reduced by the presence of $\mathrm{CO}_{2}$ and $\mathrm{CH}_{4}$ gases that are generated from organic matter early in the burial history (Tissot and Welte, 1984). $\mathrm{CO}_{2}$ gas is injected to enhance oil production from reservoirs (Abedini et al., 2014). $\mathrm{CO}_{2}$ gas might reduce the viscosity of heavy oil by three orders of magnitude (Zhou, 2018; Behzadfa and Hatzikirakos, 2014) due to the development of $\mathrm{CO}_{2}$ gas bubbles within the oil which causes the volume of $\mathrm{CO}_{2}$-oil mixture to increase by some $30 \%$ at confining pressures between 30 bar and 70/100bar (Abedini et al., 2014). The solubility of $\mathrm{CO}_{2}$ in oil increases with increasing $\mathrm{API}^{\circ}$ (Zhang, et al., 2010) which implies that $\mathrm{CO}_{2}$ might cause the expelled oil to be preferentially enriched in low-molecular oil.

$\mathrm{CO}_{2}$ gas also causes solid organic matter to swell by a few percent (Tesson and Firoozabadi, 2019). The net effect of increased $\mathrm{CO}_{2}$-gas in oil is therefore a significant volume expansion of the millimetre to sub-millimetre thin organic lamina which lifts the overburden resulting in the development of tensional fractures (Mandl and Harkness, 1987). Initially the fractures will grow as an extension of the sub-horizontal organic laminae (Mandl and Harkness, 1987), but they are anticipated to be redirected toward a strictly horizontal orientation, and perpendicular to the vertical rock stress, since this is the only direction fractures can propagate and generate space without increasing the local rock pressure/stress which would stop the fractures.

Also, if fractures remain bed-parallel, they will eventually stop propagating, probably within a few metres, since the supply of oil from a single organic lamina is limited. However, by remaining horizontal, the fractures will cut through other laminae which will serve to rejuvenate the fracture with pressurised oil. The fractures are therefore predicted to be able 
to grow within the source rock and possibly into and through adjacent mudstones. Such fractures will thus propagate in a direction of lower potential energy (Hubbert and Willies, 1973), that is, away from overburden height.

The sizes of the fracture openings are undetermined, but there are reports of pollens being derived from the same source rock as the reservoir oil suggesting that the fracture openings can be a few tens to $100 \mu \mathrm{m}$ in diameter (Jiang, 1988) which is also enough to accommodate the 50-200nm self-associated particles of asphaltenes and resins that are common constituents in heavy oil (Meyer et al., 2007; Zhao and Shaw, 2007).

The rate of oil expulsion from source rocks for any given oil is predicted to be controlled by the overburden lateral pressure gradient. A surface topography of $0.1^{\circ}$ will generate a lateral pressure gradient of $\sim 20 \mathrm{~Pa} / \mathrm{m}\left(2 \cdot 10^{-4} \mathrm{bar} / \mathrm{m}\right)$. If one assumes 10 fractures per (vertical) meter and a fracture opening of 10 and $100 \mu \mathrm{m}$ the rock horizontal permeability will be $10^{-15} \mathrm{~m}^{2}$ $(1 \mathrm{mD})$ and $10^{-12} \mathrm{~m}^{2}(1 \mathrm{D})$, respectively. If the oil viscosity is set to $0.01 \mathrm{~Pa} \cdot \mathrm{s}$, which is close to the average for conventional crude oil (Meyer et al., 2007), the lateral flux will be $6 \cdot 10 \mathrm{~m}^{1}$ and $6 \cdot 10^{4} \mathrm{~m}^{3}$ per $\mathrm{m}^{2}$ cross section in one million years which translates to a total flux of oil through a cross section area of $10^{4} \mathrm{~m}^{2}(10 \mathrm{~m} \times 1000 \mathrm{~m})$ of $6 \cdot 10^{5}$ and $6 \cdot 10^{8} \mathrm{~m}^{3}$ per million years, respectively which is substantial.

If the fractures encounter a highly permeable reservoir rock the oil pressure is expected to go from lithostatic to hydrostatic causing the $\mathrm{CO}_{2}$-gas bubbles (dispersed in the oil as in foam) to expand resulting in the $\mathrm{CO}_{2}$-oil mixture becoming more buoyant and less viscous. Hence, the oil will migrate updip, along permeable rocks, until it is trapped if a seal present. If the oil is not trapped during updip subsurface migration to the surface a sealing asphaltene tar mat might form where the reservoir is subaerially exposed due to preferentially loss of the light oil by evaporation and/or bacterial degradation (Hunt, 1995).

After pooling in a subsurface reservoir, the oil will lose most of its gases $\left(\mathrm{CO}_{2}, \mathrm{CH}_{4}, \mathrm{C}_{2} \mathrm{H}_{6}\right.$, $\mathrm{C}_{3} \mathrm{H}_{8}, \mathrm{H}_{2} \mathrm{~S}, \mathrm{~N}_{2}$ ) by diffusion and go through both chemical and structural changes which increase the viscosity (Mehrotra and Svrcek, 1988; Lesueur, 2009). Notably, both heavy oil and bitumen contain radioactive elements (Bell, 1960). Irradiation ( $\gamma$-rays) is known to break $\mathrm{C}-\mathrm{H}$ bonds and to generate free radicals which results in cross-linking and polymerization, increasing the average molecular weight of the non-hydrocarbons (NSOs) and aromatics (i.e., 
unsaturated hydrocarbons) and resulting in increased oil viscosity after pooling (Mouazen et al., 2013) unless heated due to burial.

The mobilizing effect of $\mathrm{CO}_{2}$ vanishes when $\mathrm{CO}_{2}$ gas liquifies at pressures higher than 70 100 bar and temperatures less than $50^{\circ} \mathrm{C}$ (Abedini et al., 2014). Since organic matter is defined as a viscoelastic fluid (Schneider, 1993) and because $\mathrm{CO}_{2}$ is generated within the load bearing organic matter, the $\mathrm{CO}_{2}$ gas will experience a pressure equal to the overburden rock pressure between 70 and 100 bar at 350 to $500 \mathrm{~m}$ burial (assuming minor water depths). At greater depths of burial $\mathrm{CO}_{2}$ gas becomes a fluid, and the $\mathrm{CO}_{2}$-oil mixture shrinks to a volume less than the original fluid (Abedini et al., 2014) causing viscosity to increase. Peak expulsion is therefore predicted to take place between 200 and $350 / 500 \mathrm{~m}$ of burial (assuming minor water depth).

The idea that $\mathrm{CO}_{2}$ might mobilize oil in source rocks was recognized by Momper (1978) although he did not discuss/realize the importance of $\mathrm{CO}_{2}$ being in a gas phase. Bedsides, Momper (1978) concluded that peak oil generation post-dated generation of $\mathrm{CO}_{2}$ and therefore that little or any $\mathrm{CO}_{2}$ is available during oil expulsion.

\section{In-reservoir maturation of oil by external supply of hydrogen}

In-reservoir maturation of oil due to increased temperature is a problem (e.g., Milner et al., 1977) since hydrogen-to-carbon ratios in reservoir oils increase with burial depth (Pratt, 1934; Evans et al., 1971; Connan et al., 1974, Tissot and Welte, 1984; Hunt, 1995). Hydrogen must therefore be added to form light oil (Evans et al., 1971). The only viable source of hydrogen during artificial thermal maturation of oil is asphaltene and aromatic molecules which dehydrogenate and precipitate as coke/bitumen (Connan et al. 1974). Typically, more than $20 \%$ of the oil precipitates as coke/bitumen in the laboratory (Hendersen and Weber, 1965; Rogers et al, 1972, Connan et al., 1974) but such amounts of bitumen are normally not observed in reservoir core samples from the subsurface (Evans et al., 1971; Connan et al., 1974) suggesting that in-reservoir maturation is not a realistic process.

However, if a few grams of hydrogen are added for every kilogram of immature oil, as is commonly done in oil refineries, the asphaltene and aromatics are hydrogenated/hydrocracked and converted to paraffinic hydrocarbons (Rollmann, 1976; 
Korre et al., 1994; Ancheyta, et al. 2005; Shan et al., 2017). If hydrogen were supplied to pooled oil in the subsurface, as suggested by Pratt (Pratt, 1934), immature and heavy oil might be converted to mature and light oil without precipitation of significant amounts of bitumen. Subsurface hydrogen, however, is not normally measured (Hunt, 1979), although it is a common constituent in subsurface fluids and often makes up more than $10 \%$ by volume of the associated gases (Hunt, 1979; 1995; Zgonnik, 2020). Indeed, Hunt (1972) estimated that there is approximately 30 times more hydrogen in sedimentary basins than the amount of hydrogen in pooled petroleum of sedimentary rocks.

The origin of some of the hydrogen in the subsurface might originate from the mantle (Zgonnik, 2020), although a significant proportion is likely to have been generated from coalification of organic matter in mudstones (Hunt, 1972; Hunt, 1979) resulting in a reduction in the hydrogen-carbon ratio with depth. The hydrogen-carbon ratio of organic matter in source rock at the beginning and at the end of today's oil expulsion window (120 $150^{\circ} \mathrm{C}$ ) is typically 1.3 and 0.7 , respectively (Baskin, 1997; Behar and Vandenbroucke, 1987) which translates to hydrogen loss of more than $4 \%$ by weight (relative to organic carbon). This reduction in hydrogen in source rock organic matter is generally perceived as due to the expulsion of hydrocarbons since they have a higher hydrogen-carbon ratio than organic matter (Baskin, 1997; Hunt, 1995).

However, as shown in Figure 1, the amount of organic carbon does not decrease within today's oil window suggesting that none or very little carbon, and therefore, hydrocarbons, has left the source rock during the $120-150^{\circ} \mathrm{C}$ window. This implies that most of the hydrogen leaves the organic matter as hydrogen. Indeed, every kilogram of organic carbon will generate approximately $40 \mathrm{~g}$ hydrogen and a source rock with $5 \%$ organic carbon will produce $2000 \mathrm{~g}$ of hydrogen molecules $\left(\mathrm{H}_{2}\right)$, per ton of rock within today's oil window. This means that more than $90 \%$ of the hydrogen generated from a good source rock ends up as free gas because of limited solubility of hydrogen in water (Wieber and Gaddy, 1934), oil (Cai, et al., 2001) and organic matter (Ji et al., 2013).

The average amount of organic carbon in mudstones is around 1\% (Hunt, 1972). If one assumes a weight loss of $2 \%$ due to release of hydrogen, every ton of mudstone will generate around $200 \mathrm{~g}$ hydrogen implying that probably all hydrogen molecules will be 
molecularly dissolved in the pore waters, which is significant. This implies that every $\mathrm{km}^{3}$ of mudstone might produce $\sim 5 \times 10^{11} \mathrm{~g}$ hydrogen. It is enough to convert $2 \times 10^{8}$ ton $(\sim 1.5$ billion barrels) of low-quality naphthenic oil to high-quality paraffinic oil. Even if only $10 \%$ of the hydrogen is consumed, it is still a large number.

The hydrogen solubility in heavy oil at 100 bar and $50^{\circ} \mathrm{C}$ is less than $0.2 \mathrm{~g}$ per kilogram (Cai, et al., 2001) which is more than ten times less than the amount of hydrogen required to convert $1 \mathrm{~kg}$ heavy oil to light oil (Ancheyta, et al. 2005). Most of the hydrogen must therefore be supplied from the water phase after accumulation. The solubility of hydrogen in water at $100 \mathrm{bar}$ and $50^{\circ} \mathrm{C}$ is $0.2 \mathrm{~g}$ per kilogram (Wiebe and Gaddy, 1934). Most of the hydrogen required to convert naphthenic heavy oil to light paraffinic oil must therefore be supplied by molecular diffusion through the water phase which might explain why the amount of hydrogen is reported to decrease close to oil accumulations (Zgonnik, 2020).

Supply of hydrogen molecularly dissolved in the water phase is expected be a slow process which might explain why young, rapidly subsiding oil accumulations are less mature than older, slower subsiding oil accumulations positioned at similar temperatures (Barton, 1934, McNab et al., 1952). The implication is that time can compensate for low temperature with regards to oil maturity/ quality. Consequently, the disputed time-dependent (kinetic) explanation for generation of hydrocarbons (Dominé et al., 1988; Schneider, 1993; Price and McNeil, 1997) can probably be replaced by an approach assuming thermodynamic equilibrium in pooled oils and that the molecular composition of the hydrocarbons in most cases is controlled by the rate at which hydrogen is supplied to the reservoir.

The size of the oil accumulation also matters. The transport-rate limited model for supply of hydrogen predicts that exceptionally large oil accumulations mature at a slower rate than much smaller oil accumulations. The super-giant heavy oil $\left(\mathrm{API}<22^{\circ}\right)$ Cantarell field in Mexico, where the reservoir temperature is $115^{\circ} \mathrm{C}$ (Nadeau et al. 2005), might be an example of a size-related retarded maturation by restricted supply of hydrogen.

Insufficient supply of hydrogen might also explain why some oils have not been cracked to gas at reservoir temperature of $200^{\circ} \mathrm{C}$ and higher as reported by (Dominé et al. (1988), Waples (2000) and Zhu et al. (2018). Also, total lack of an external supply of hydrogen might 
be the reason why oil and biomolecules trapped in mineral cements are reported to have endured for more than 2 billion years at maximum temperature higher than $280^{\circ} \mathrm{C}$ and probably as high as $350^{\circ} \mathrm{C}$ (George et al., 2008).

Variation in supply of hydrogen to the oil within a reservoir might also explain the origin of enigmatic tar mats (Wilhelms and Larter, 1994). If some fraction of the oil is heated in the absence of supply of hydrogen the immature oil is expected to evolve on a path toward bitumen, like the hydrogen-starved bitumen formed during artificial heating of immature oil (Hendersen and Weber, 1965). Once formed, bituminous tar mats are likely to resist hydrogenation (and conversion to paraffinic oil) since the hydrogen solubility is lower in bitumen than in light oil (Ji et al., 2013; Cai, et al., 2001) which means that the supplied hydrogen is expected to be preferentially dissolved in and consumed by the maturing light oil phase.

Presence of hydrogen in subsurface fluids was recognized during the 1970s (Hunt, 1972; 1979), but hydrogen was not considered necessary to explain the quality of reservoir oil (Hawkes, 1972) since most of the hydrocarbons were assumed to have been generated within the source rocks prior to expulsion (Hunt, 1979).

\section{Discussion}

The proposed model for oil expulsion from source rocks suggests that the expulsion efficiency is related to the amount of $\mathrm{CO}_{2}$ generated early in the burial history. Freshwater organic matter is assumed to generate most oil per kilogram of organic carbon (Baskin, 1997; $Q \& M, 1988$ ) but it generates by far the least amount of $\mathrm{CO}_{2}$ (Tissot and Welte, 1984) and is therefore predicted to be the least efficient oil source rock. Marine algal (Type II) and terrestrial land plant (Type III) source rocks are known to lose approximately $25 \%$ and $50 \%$ weight, respectively, due to the generation of $\mathrm{CO}_{2}\left(\right.$ and $\left.\mathrm{H}_{2} \mathrm{O}\right)$ during the first few hundred meters of burial (Tissot and Welte, 1984).

Except for the first 30m (Smith, 1952a,b; 1954), reliable source rock data covering the upper 1.5 km sedimentary section are missing (Cordell, 1972; Tissot and Welte, 1984; Hunt, 1995) which makes it impossible to document or test the shallow oil expulsion model from TOC data. 
The volume of expelled oil is therefore uncertain. However, Hunt (1995) noticed that about 40 to $60 \%$ of fresh organic matter is soluble in acids, bases, and organic solvents, compared with less than $20 \%$ of the organic matter in lithified rocks suggesting that the fraction of $\mathrm{CO}_{2}$ mobilizable oil in source rocks is likely to be less than 20 to $40 \%$ of the total original organic matter.

The $\mathrm{CO}_{2}$ - gas flushing model also suggests that oil might not be expelled from source rocks deposited at water depths greater than $1000 \mathrm{~m}$ since the $\mathrm{CO}_{2}$ will be liquified at 100 bars. The presence of methane gas will cause some volume expansion of organic matter and oil (Bazyleva et al., 2013) implying that horizontal fractures might form, but the oil viscosity is not significantly reduced since the effects of methane on oil viscosity is less than compared to $\mathrm{CO}_{2}$ (Bazyleva et al., 2013).

The single most important thing to recognize is that hydrogen gas is common in subsurface fluids matter since it affects the evolution of all organic matter during burial. The notable supply of hydrogen might explain why terrestrial (Type III) organic matter, despite its higher content of non-hydrocarbon structures and low hydrogen-carbon ratio compared with marine (Type II) organic matter (Behar and Vandenbroucke, 1987), might also be an important source for high quality liquid hydrocarbons in deeply buried reservoirs.

The presence of hydrogen is expected to be important for shale oil plays where the nonexpelled oil is targeted (Hill et al., 2007). Abundant in-situ supply of hydrogen (from organic matter) might explain why oil appears to be cracked to gas at much lower thermal maturation levels than predicted by today's model (Hill et al., 2007).

Similarly, in-situ generated hydrogen might explain why most of the oil associated with dispersed organic matter in mudstones appears to be converted to gas at temperature less than $100^{\circ} \mathrm{C}$ (Albrecht et al., 1976; Hunt, 1979) which is more than $50^{\circ} \mathrm{C}$ lower than the beginning of the predicted gas generation window (Mackenzie and Quigley, 1988).

The presence of molecular hydrogen in subsurface fluids is also likely to affect the thermal evolution of organic macerals (e.g., spores/vitrinite) and might therefore jeopardize vitrinite reflectance, $R_{\circ}$, measurements which are used as a proxy for thermal stress (Hunt, 1995) and to calibrate basin modelling programs (Cooles et al., 1986). The ability to reflect light stems 
from flat light-reflecting polyaromatic sheets developed by the dehydrogenation of twisted (non-reflecting) cycloalkanes (Tissot and Welte, 1984 1984). The presence of hydrogen will impede or even reverse development of light-reflecting (flat) aromatic structures (Korre et al., 1994). Variation in the supply of hydrogen might therefore explain why $R_{\circ}$ differs in sandstones, mudstones, and limestones from the same stratigraphic section (Price and Baker, 1985). Hence, abundant in-situ generated hydrogen gas might explain why vitrinite reflectance of samples from source rocks are significantly suppressed (Fang and Jianyu, 1992 ) as illustrated by vitrinite reflectance of $0.6 \%$ in source rocks at $120^{\circ} \mathrm{C}$ (Cooles et al., 1986) while vitrinite reflectance in reservoir rocks, where the supply of hydrogen is likely to be less, it is typically close $1.2 \%$ at $120^{\circ} \mathrm{C}$ (Hunt, 1979).

The model presented for timing of expulsion of oil and lateral migration via horizontal fractures into nearby traps lends support to the pre-1970 model by providing possible explanations to some of its unresolved issues and implies that many of the enigmas associated with today's model (Wilson, 1990; Wilson, 2005) can be put aside, notably the long-distance sub-horizontal (up to $400 \mathrm{~km}$ ) secondary oil migration required to explain the major accumulations in Eastern Venezuela and Western Canada for example (Hunt, 1995).

The new expulsion model suggests that most of the oil accumulations are locally sourced and that some $1 / 3$ of the pooled oil are buried and upgraded to conventional light oil by the combined effect of higher temperature $\left(60-70^{\circ} \mathrm{C}\right)$ and external supply of hydrogen. Oil is likely to leak from the trap via hydro-fractures (Engelder and Leftwich, 1997) at temperatures higher than $120^{\circ} \mathrm{C}$ (Bjørkum and Nadeau, 1998) which might explain why nearly all the oil is produced from reservoir with temperatures less than $120^{\circ} \mathrm{C}$ (Hedberg, 1964; Nadeau et al., 2005).

\section{Conclusions}

Data from North Sea source rocks between 3.5 and $4.5 \mathrm{~km}$ burial depths, corresponding to 120 to $150^{\circ} \mathrm{C}$, show that the amount of organic carbon (TOC) does not decline within the oil expulsion window between 120 and $150^{\circ} \mathrm{C}$ as predicted by today's model. To the authors knowledge, a decline in TOC as predicted has not been documented from other source rocks either. Also, pooled oils have some chemical and physical attributes that conflict with 
today's expulsion temperature model but are rather more consistent with the pre-1970 models that claimed that most oil is expelled at relatively shallower depths and at much lower temperatures.

Chemical data from heavy oil accumulations shows that they have not experienced temperatures much higher than $70^{\circ} \mathrm{C}$ which implies that most heavy oil is not biodegraded light oil as argued by most of today's organic geochemists.

In this paper the shallow/early oil expulsion model advocated by most oil explorer prior to 1970, is revitalized and improved. It is argued that oil expulsion from source rocks is propelled by $\mathrm{CO}_{2}$ gas generated from laminated organic matter early in the burial history. $\mathrm{CO}_{2}$ gas causes the organic lamina to swell, creating horizontal fractures through which the oil is subsequently expelled.

$\mathrm{HC}$ will migrate out of the source rock in the direction of lower overburden rock pressure until it enters reservoir rocks or carrier beds that transport the oil to reservoir traps or to the Earth's surface.

Most of the reduction in the $\mathrm{H} / \mathrm{C}$-ratio in organic matter during burial is due to loss of hydrogen gas. This is evident from the fact that $\mathrm{H} / \mathrm{C}$ ratio is decreases while the amount of organic carbon, TOC, remains close to constant.

Hydrogen is produced from dispersed organic matter in mudstones and source rocks due to thermally driven coalification of the organic matter. Most of the generated hydrogen becomes molecularly dissolved in the water phase.

Presence of hydrogen gas will supress aromatization of cycloalkanes in solid organic matter and therefore its ability to reflect light which might explain why vitrinite reflectance $\left(R_{0}\right)$ is lower in samples from source rocks compared to reservoirs at the same burial depths.

In the proposed model, immature oil is converted to mature (paraffinic) oil within the reservoir starting at temperatures of $60-70^{\circ} \mathrm{C}$. Precipitation of bitumen is prevented since hydrogen generated from coalification of organic matter in mudstones and source rocks is supplied to the pooled oil where it is consumed in the conversion of non-hydrocarbons (i.e., 
asphaltene and resins) to paraffinic hydrocarbons as in refineries. Since hydrogen is supplied to the pooled oil it suggests that the original composition of source material for the reservoir oil, either marine or terrestrial, might not be critical for the oil quality at temperatures higher than $70-100^{\circ} \mathrm{C}$ unless the supply of hydrogen is limited.

The molecular composition of the reservoir oil at any given temperature will be influenced by the rate at which hydrogen is supplied to the reservoir oil by molecular diffusion in the water phase, which might be a rate-limiting process. Large oil accumulations might therefore mature at slower rates than smaller accumulations. Insufficient supply of hydrogen might also explain why some oils have not been converted to gas at temperatures higher than $200^{\circ} \mathrm{C}$.

It is also postulated that reservoir tar mats originate from in-situ maturation of immature oil due to a restricted supply of hydrogen, like the bitumen formed during thermal maturation of immature oil under laboratory conditions and in refineries, without extra supply of hydrogen.

It appears that artificial high-temperature pyrolysis of organic matter, like Rock-Eval, does not replicate normal processes within the source rock but rather produces synthetic oils like in refineries.

The main implication for oil exploration is that low and/or high-quality oils can be found in basins and subbasins where source rocks have not experienced temperatures higher than $120^{\circ} \mathrm{C}$, which according to today's geochemical model represents a minimum temperature for significant expulsion of oil, thus potentially extending the petroleum envelope into areas where source rocks are currently considered immature and non-prospective.

\section{Acknowledgements}

The views and opinions expressed in this article are those of the author and do not reflect the views or work processes of Equinor ASA or any of its subsidiaries. I am grateful to many of my colleagues for helpful comments in the early stages of this work, and too $\varnothing y v i n d$ Steen for preparing Figure 1. I also want to thank Benjamin Cements and Phillip W. Mullis for improving the manuscript. 


\section{Declaration}

The author of this paper has no interests that conflict with its content.

\section{References}

Abedini, A., N. Mosavat, and F. Torabi, 2014, Determination of Minimum Miscibility Pressure of Crude oil- $\mathrm{CO}_{2}$ System by Oil Swelling/Extraction Test: Energy Technology, v. 2, p. 431-439. https://onlinelibrary.wiley.com/doi/10.1002/ente.201400005

Albrecht, P., M. Vandenbroucke and M. Mandengué, 1976, Geochemical studies on the organic matter from the Douala Basin (Cameroon)-I. Evolution of the extractable organic matter and the formation of petroleum: Geochimica et Cosmochimica Acta. v. 40. p. 791 to 799.

https://www.sciencedirect.com/science/article/abs/pii/0016703776900314

Ancheyta, J., S. Sánchez, and M. Rodríquez, 2005, Kinetic modelling of hydrocracking of heavy oil: A review: Catalysis Today, v. 109, p. 76-92.

https://www.sciencedirect.com/science/article/pii/S0920586105005973

Ball, M. W. 1935, Athabasca oil sands: apparent example of local origin of oil, Bulletin of the American Association of Petroleum Geologist, v. 19, p. 153-171. https://doi.org/10.1306/3D932CE016B1-11D7-8645000102C1865D

Banks, L. M., 1966, Geologic Aspects of origin of petroleum: DISCUSSION, Bulletin of the American Association of Petroleum Geologists, v. 50. p. 397-400.

https://doi.org/10.1306/5D25B49B-16C1-11D7-8645000102C1865D

Barton, D. C., 1934, Transformation of Petroleum in Nature: Journal of Institute of Petroleum Technologists, v. 20. p. 206-213.

Baskin, D. K., 1997, Atomic H/C Ratio of Kerogen as an Estimate of Thermal Maturity and Organic Matter Conversion, American Association of Petroleum Geologists Bulletin, v. 81, No. 9, p. 14371450. https://doi.org/10.1306/3B05BB14-172A-11D7-8645000102C1865D

Bazyleva, A., B. Akeredolu, B. and M. W. Liberatore, 2013, Viscosity of Alaska Heavy Oil Saturated with Methane: Energy Fuels, v. 27, p. 743-751. https://pubs.acs.org/doi/abs/10.1021/ef301757v Behar, F., and M. Vandenbrocke, M., 1987, Chemical modelling of kerogen: Organic Geochemistry, v. 11, p. 15-24. https://www.osti.gov/etdeweb/biblio/5753931 
Bell, K. G., 1960, Uranium in carbonaceous rocks, in Uranium and Other Trace Elements in Petroleums and Rock Asphalts: Geological Survey Professional Paper 356-B, United states government printing office, Washington, p. 45-71. https://doi.org/10.3133/pp356B

Belonin, M. D., and V. I. Slavin, 1998, Abnormally high formation pressures in petroleum regions of Russia and other countries of the C.I.S., in B. E. Law, G. F. Ulmishek, and V. I. Slavin, eds., Abnormal pressures in hydrocarbon environments: American Association of Petroleum Geologists Memoir 70, p. 115-121. https://archives.datapages.com/data/specpubs/memoir70/m70ch07/m70ch07.htm Bjørkum, P. A., and P. H. Nadeau, P. H., 1998, Temperature controlled porosity/permeability reduction, fluid migration, and petroleum exploration in sedimentary basins, Australian Petroleum Production \& Exploration Association Journal, v. 38, p. 453-464. https://doi.org/10.1071/AJ97022

Buckley, S. E., C. R. Hocott, and M. S. Jr. Taggart, 1958, Distribution of dissolved hydrocarbons in subsurface waters, in L. G. Weeks (ed), Habitat of oil: A symposium: American Association of Petroleum Geologists, p. 580-882.

https://archives.datapages.com/data/specpubs/basinar2/data/a125/a125/0001/0850/0850.htm

Cai, H. Y., SJ. M. haw, and K. H. Chung, 2001, Hydrogen solubility measurements in heavy oil and bitumen cuts: Fuel, v. 80, p. 1055-1063. https://doi.org/10.1016/S0016-2361(00)00171-X

Connan, J., K. Le Tran, and B. van der Weide, 1975, Alteration of Petroleum in Reservoirs. In $9^{\text {th }}$ World Petroleum Congress, Proc. v. 2, London: Applied Science Publisher, p. 171-178. https://onepetro.org/WPCONGRESS/proceedings/WPC09/All-WPC09/WPC-16116/199255

Cooles, G. P., A. S. Mackenzie, and T. M. Quigley, 1986, Calculation of petroleum masses generated and expelled from source rocks: Advances in Organic Geochemistry, v. 10, pp. 235245, 1986.

https://www.sciencedirect.com/science/article/abs/pii/0146638086900264

Cordell, R. J,..1972, Depth of oil origin and primary migration: a Review and Critique: Am. Assoc. Petroleum geologists. v. 56, p. 2029-2067.

https://doi.org/10.1306/819A41AC-16C5-11D7-8645000102C1865D

Dominé, F., D. Dessort, and O. Brévart, 1998, Towards a new method of geochemical kinetic modelling: implications for the stability of crude oils: Organic Geochemistry. v. 28, p. 597-612. https://doi.org/10.1016/S0146-6380(98)00030-8 
Dott, R. H. Sr., and M. J. Reynolds, 1969, Sourcebook for Petroleum, in R. H. Sr. Dott, and M. J. Reynolds, eds., American Association of Petroleum Geologists Special Volume Memoir 5, 445 p. Electronic Index of AAPG Special Publications:

England, W. A., 1994, Secondary migration and Accumulation of hydrocarbons, in Magoon, L. B., and G. Dow, eds., The petroleum system - from source to trap: American Association of Petroleum Geologists Memoir 60, p. 211-217.

https://archives.datapages.com/data/specpubs/methodo2/data/a077/a077/0001/0200/0211.htm

Engelder, T., and J. T. Leftwich, Jr., 1997, A pore-pressure limit in overpressured South Texas oil and gas fields, in R. C. Surdam, ed., in Seals, traps, and the petroleum system: American Association of Petroleum Geologists Memoir 67, p. 255-267.

https://archives.datapages.com/data/specpubs/mem67/ch15/ch15.htm

Erdmann, J. G., 1965, Petroleum-its origin in the earth, in Fluids in Subsurface Environments, A. Young and J. E. Galley, eds.: American Association of Petroleum Geologist Memoir 4, p. 20-52. https://archives.datapages.com/data/specpubs/methodo2/data/a071/a071/0001/0000/0020.htm

Evans, C. R., M. A. Rogers, and N. J. L. Bailey,, 1971, Evolution and alteration of petroleum in western Canada: Chemical Geology., v. 8, p. 147-170.

https://doi.org/10.1016/0009-2541(71)90002-7

Fang, H., and C. Jianyu, 1992, The Cause and mechanism of vitrinite reflectance anomalies: Journal of Petroleum Geology, v. 15, p. 419-434.

https://onlinelibrary.wiley.com/doi/10.1111/j.1747-5457.1992.tb01043.x

Farrimond, P., and A. Taylor, and N. Telnæs, 1998, Biomarker maturity parameters: the role of generation and thermal degradation: Organic Geochemistry, v. 29, p. 1181-1197.

https://doi.org/10.1016/S0146-6380(98)00079-5

George, A. E., R. C. Banerjee, R. C., G. T. Smiley, and H. Sawatzky, H., 1977, Simulated geothermal maturation of Athabasca bitumen: Bulletin of Candian Petroleum Geology, v. 25, p. 1085-1096. https://doi.org/10.35767/gscpgbull.25.5.085

George, S. C., H. Volk, A. Dutkiewicz, J. Ridley, and R. Buick, 2008, Preservation of hydrocarbons and biomarkers in oil trapped inside fluid inclusions for $>2$ billion years: Geochimica et Cosmomchimica Acta, v. 72, p. 844-870. https://doi.org/10.1016/i.gca.2007.11.021 
Gester, G. C., 1947, Report of sub-committee on reservoir fluids, related constituents and conditions: Bulletin of American Association of Petroleum Geologist, v. 31, p. 375-394. https://doi.org/10.1306/3D933965-16B1-11D7-8645000102C1865D Hawkes, H. E., 1972, Free hydrocarbon in genesis of petroleum: American Association of Petroleum Geologists, v. 56. p. 2268-2277. https://doi.org/10.1306/819A4202-16C5-11D7-8645000102C1865D Head, I. M., D. M. Jones, and S. R. Larter, 2003, Biological activity in the deep subsurface and the origin of heavy oil: Nature, v. 426, , p. 344-352. https://www.nature.com/articles/nature02134 Head, I. M., S. R. Larter, N. D. Gray, A. Sherry, J. J. Adams, C. M. Aitken, D. M. Jones, A. K. Rowan, H. Huang, W. F. M. Röling, 2003, , 2010, Hydrocarbon Degradation in Petroleum Reservoirs, in K. N. Timmins, ed.: Handbook of Hydrocarbon and Lipid Microbiology, Springer, Heidelberg, Germany, ( $p$. 3097-3109.

https://www.infona.pl/resource/bwmeta1.element.springer-cc45b4d2-188e-3afd-9e01$\underline{5 e 214 c 0 c 3313}$

Hedberg, H. D, 1954, World oil prospects - from a geological viewpoint: Bulletin of American Association of Petroleum Geologists, v. 38, n. 8, p. 1714-1724.

https://doi.org/10.1306/5CEAE022-16BB-11D7-8645000102C1865D

Hedberg, H. D., 1964, Geologic aspects of origin of petroleum: American Association of Petroleum Geologists Bulletin, v. 48, no. 11, p. 1755-1803.

https://doi.org/10.1306/BC743DB7-16BE-11D7-8645000102C1865D

Hedberg, H. D., L. C. Sass, and H. J. Funkhouser, 1947, , Oil Fields of Greater Oficina area Central Anzoátegui Venezuela: Bulletin of American Association of Petroleum Geologists, v. 31, p. 2089-2169. https://pubs.geoscienceworld.org/aapgbull/article-abstract/31/12/2089/33296/Oil-fields-of-Greater$\underline{\text { Oficina-area-central }}$

Henderson, J. H., and L. Weber, 1965, Physical Upgrading of Heavy Crude oils by the application of heath: Journal of Canadian Petroleum Technology, v. 4. p. 206-2012.

https://doi.org/10.2118/65-04-05

Hirschberg, A., 1998, Role of asphaltenes in compositional grading of reservoir's fluid column: Journal of Petroleum Technology, v. 40, p. 89-94. https://doi.org/10.2118/13171-PA 
Hill, R. J., E. Zhang, B. J. Katz, and Y. Tang, 2007, Modelling of gas generation from Barnett Shale Fort Worth Basin, Texas: American Association of Petroleum Geologists Bulletin, v. 91, p. 501-521. https://doi.org/10.1306/12060606063

Huang, H., and S. R Larter, 2005, Biodegradation of petroleum in subsurface geological reservoirs, Petroleum Microbiology, p. 91-120

https://onlinelibrary.wiley.com/doi/abs/10.1128/9781555817589.ch6

Hunt, J. M., 1972, Distribution of carbon in crust of earth: American Association of Petroleum Geologists Bulletin, v. 56, p. 2273-2277.

https://doi.org/10.1306/819A4206-16C5-11D7-8645000102C1865D

Hunt, J. M., 1979, Petroleum Geochemistry and Geology, 1st ed., : W. H. Freeman, San Francisco, 617 p.

Hunt, J. M., 1995, Petroleum Geochemistry and Geology, 2nd ed., : W. H. Freeman, San Francisco, $743 \mathrm{p.}$

Ishiwatari, R., M. Ishiwatari, B. G. Rohrback and I. R. Kaplan, 1977, Thermal alteration experiments on organic matter from recent marine sediments in relation to petroleum genesis: Geochimica et Cosmochimica Acta, v. 41. p. 815 - 828. https://doi.org/10.1016/0016-7037(77)90052-7

Ji, S., Z. Wang, Y. Guo, A. Shou, and K. Chen, 2013, Determination of hydrogen solubility in heavy fraction of crude oils by a modified direct method: Journal of Chemical Engineering Data, 2013, v.58., p. 3453-3457. https://pubs.acs.org/doi/abs/10.1021/ie400729v

Jiang, D. ,1988, Spores and pollen in oils as indicators of lacustrine source rocks, in A. J. Fleet, and K. Kelts, and M. R. Talbot, eds., Lacustrine Petroleum Source Rocks: Geological Society Special Publication, nNo. 40, p. 159-169. https://doi.org/10.1144/GSL.SP.1988.040.01.15

Jobson, A., F. D. Cook, and D. W. S. Westake, 1972, Microbial utilization of crude oil:, Applied Microbiology. v. 23, p. 1082-1089. https://journals.asm.org/doi/10.1128/am.23.6.1082-1089.1972 Kenvolden, K. A., andC. K. Cooper, 2003, Natural seepage of crude oil into the marine environment: Geo-Marine Letters, v. 23, p. 140-146. https://link.springer.com/article/10.1007/s00367-003-0135-0 Klemme, H. D., 1975, Gigant oil fields related to their geological settings: A possible guide to exploration: Bulletin of Canadian Petroleum Geology, v. 23, p. 30-66.

https://doi.org/10.35767/gscpgbull.23.1.030 
Korre, S. C., M. Neurock, , M.T. Klein, M. T.,and R. . Quiann, 1994, Hydrogenation of polynuclear aromatic hydrocarbons. 2. Quantitative structure/reactivity correlations: Chemical Engineering Science, v. 49, p. 4191- 4210. https://doi.org/10.1016/S0009-2509(05)80015-6

Larter, S. R,, A. Wilhelms, I. Head, M. Koopmans, A. Aplin, R. Di Primio, C. Zwach, M. Erdmann, and N.Telnaes, 2003, The controls on the composition of biodegraded oils in the deep subsurface-part I:biodegradation rates in petroleum reservoirs: Organic Geochemistry, v. 34, p. 601-613. https://doi.org/10.1016/S0146-6380(02)00240-1

Larter, S.R. H. Huang, J. Adams, B. Bennett, O. Jokanola, ; T. Oldenburg, M. Jones, I. Head, C. Riediger, and M. Fowler, 2006, The controls on composition of biodegraded oils in the deep surface. Part II -Geological controls on subsurface biodegradation fluxes and constraints on reservoir-fluid property prediction: American Association of Petroleum Geologists Bulletin, v. 90, p. 921-938. https://doi.org/10.1306/01270605130 Lesueur, D., 2009, The colloidal structure of bitumen: consequences on the rheology and on the mechanism of bitumen modification: Advances in Colloid Interfaces Science, v. 145 , p. 42-82. https://doi.org/10.1016/i.cis.2008.08.011

Lewan, M. D., T. E. Ruble, 2002. Comparison of petroleum generation kinetics by isothermal hydrous and non-isothermal open-system pyrolysis:. Organic Geochemistry, v. 33, p. 1457-1475. https://doi.org/10.1016/S0146-6380(02)00182-1

Mandl, G., and R. M. Harkness, R. M. 1987, Hydrocarbon migration by hydraulic fracturing. In Deformation of Sediments and Sedimentary Rocks, Jones, M. E. and R. M. Preston, eds., Geological Society Special Publication, 29, p. 39-53. https://doi.org/10.1144/GSL.SP.1987.029.01.04

McNab, P., V. Jr. Smith, V. Jr., and R. L. Betts, 1952, The Evolution of Petroleum: Industrial and Engineering Chemistry, v. 44. p. 2556- 2565.

https://pubs.acs.org/doi/pdf/10.1021/ie50515a029

Mehrotra, A.K., and W. Y. Svrcek, W. Y., 1988, Properties of Cold Lake bitumen saturated with pure gases and gases mixtures: The Canadian Journal of Chemical Engineering, v. 66, p. 565-665. https://doi.org/10.1002/cjce.5450660419 
Meyer, R. F., E. D. Attanasi,and P. A. Freemann, P. A., 2007, Heavy oil and natural bitumen resources in geological basins of the world: U.S. Geological Survey Open-file Report 2007-1084, 36 p. https://ubs.usgs.gov/of/2007/1084/p

Milner, C. W. D. M. A. Rogers, and C. R. Evans, , 1977, Petroleum transformations in reservoirs: Journal of Geochemical Exploration, v. 7. p. 101-153.

https://doi.org/10.1016/0375-6742(77)90079-6

Momper, J. A. 1978, Oil migration limitations suggested by geological and geochemical considerations, in Physical and chemical considerations on petroleum migration: American Association of Petroleum Geologists v. 1. Notes for AAPG short course National Meeting, Oklahoma City, 55 p. .

https://archives.datapages.com/data/specpubs/geochem1/data/a034b/a034/0001/0000/t1.htm

Monreal, F.R. H. J. Villar, D. D. Baudino, D. Deplino, and S. Zencich, 2009, Modelling an atypical petroleum system: A case study of hydrocarbon generation, migration and accumulation related to igneous intrusions in the Neuquen Basin, Argentina: Marine and Petroleum Geology v. 26, p. 590605. https://doi.org/10.1016/j.marpetgeo.2009.01.005

Montgomery, D. S., R. C. Banerjee, H. Sawatsky, 1974, Optical activity and the saturated hydrocarbon from the Alberta heavy Cretaceous oils and its relation to thermal maturation: Bulletin of Canadian Petroleum Geology, v. 22, p. 357-360.

https://archives.datapages.com/data/cspg/data/022/022003/0357.htm

Mouazena, M., A. Poulesquen, F. Barta, J. Masson, M. Charlot, B. Vergnes, 2013, Rheological structurers and chemical evolution of bitumen under gamma irradiation: Fuel Processing Technology, v. 114, p. 144-153. https://doi.org/10.1016/j.fuproc.2013.03.039

Nadeau, P. H., P. A., Bjørkum, P. A., and O. Walderhaug, 2005, Petroleum system analysis: impact of shale diagenesis on reservoir fluid pressure, hydrocarbon migration, and biodegradation risks, in A. G. Doré, and B. A. Vining, eds., Petroleum Geology: North-West Europe and Global Perspectives Proceedings of the 6th Petroleum Geology Conference, London, Geological Society of London, p. 1267-1274. https://doi.org/10.1144/0061267

Okiongbo, K. S. 2011, Bulk Volume Reduction of the Kimmeridge Clay Formation, North Sea (UK) Due to Compaction Petroleum Generation and Expulsion: Research Journal of Applied Sciences, Engineering and Technology. v. 3, p. 132-139.

http://citeseerx.ist.psu.edu/viewdoc/download?doi=10.1.1.1056.1623\&rep=rep1\&type=pdf 
Okiongbo, K. S., A. C. Aplin, and S. R. Larter, 2005, Changes in Type II Kerogen and Density as a function of Maturity: Evidence from the Kimmeridge Clay Formation: Energy Fuels, v. 19, p. 24952499. https://pubs.acs.org/doi/abs/10.1021/ef050194+

Parnell, J., 1993,). Chemical age dating of hydrocarbon migration using uraniferous bitumens, Czech-Polish border region, in Parnell J., H. Kucha, and P. Landais, eds.: Bitumens in Ore Deposits. Springer-Verlag, Berlin, p. 510-517.

https://link.springer.com/chapter/10.1007/978-3-642-85806-2 28

Pepper, A. S., and P. J. Corvi, 1995, Simple kinetic models of petroleum formation. Part III: Modelling an open system: Marine and Petroleum Geology, v. 12, No. 4, p. 417-452, 1995.

https://doi.org/10.1016/0264-8172(95)96904-5

Peters, K. E and M. R. Cassa, 1994, Applied Source Rock Geochemistry, in Magoon, L. B., and W. G. Dow, eds., The petroleum system - from source to trap, American Association of Petroleum Geologists Memoir No 60, p. 93-120.

https://archives.datapages.com/data/specpubs/methodo2/data/a077/a077/0001/0050/0093.htm

Pratt, W. E., 1934, Hydrogenation and the origin of oil, Part II. Origin and evolution of petroleum: Group 3. Variation in physical properties, in Problems of Petroleum Geology, In W.E. Wrather and F. H. Lahee, eds.: American Association of Petroleum Geologists p. 235-245.

https://archives.datapages.com/data/specpubs/methodo1/data/a069/a069/0001/0200/0235.htm

Price , L. C, 1993, Thermal stability of hydrocarbons in nature: Limits, evidence, characteristics, and possible controls: Geochemica et Cosmochimica Acta, 1993, v. 57, p. 3261- 3280.

https://doi.org/10.1016/0016-7037(93)90539-9

Price, L.C., and R. McNeil, 1997, Thought on the birth of evolution, and current state of petroleum geochemistry: Journal of Petroleum Geology, v. 20, p. 118-123.

https://archives.datapages.com/data/ipg/1997/01jan/0118/0118.htm

Price, L.C., and C. E. Barker, 1985. Suppression of vitrinite reflectance in amorphous-rich kerogen - A major unrecognized problem: Journal of Petroleum Geology., v. 8, p. 59-84.

https://doi.org/10.1111/j.1747-5457.1985.tb00191.x

Quigley, T. M., A. s. Mackenzie, 1988. Principles of Geochemical Prospect Appraisal, American Assoc. Petrol. Geol., v. 72, p. 399-415.

https://doi.org/10.1306/703C8EA2-1707-11D7-8645000102C1865D 
Rogers, M. A., J. D. McAlary, and J. L. Bailey, 1974. Significance of Reservoir Bitumen to thermal maturation studies: Western Canada Basin: American Association of Petroleum Geologists Bulletin, v. 58, p. 1806-1824.

https://doi.org/10.1306/83D919B6-16C7-11D7-8645000102C1865D

Rollmann, L. D., 1976, Catalytic hydrogenation of model nitrogen, sulfur, and oxygen compounds: Journal of Catalysis, v. 46. p. 234- 252.

https://doi.org/10.1016/0021-9517(77)90206-8

Sánchez, S., and J. Ancheyta, 2007, Effect of pressure on the kinetics of moderate hydrocracking of Maya crude oil: Fuel and Energy, v. 21, p. 653-661.

https://pubs.acs.org/doi/abs/10.1021/ef060525y

Schneider, H. A., 1993, Are kinetic parameters of non-isothermal thermogravimetric degradation of polymers unequivocal: Journal of Thermal Analysis, v. 40, p. 677-687.

https://akjournals.com/view/journals/10973/40/2/article-p677.xml

Scholten, R., 1959, Synchronous highs: preferential habitat of oil?: American Association of Petroleum Geologist Bulletin, v. 43, p. $1973-1834$.

https://doi.org/10.1306/0BDA5E6D-16BD-11D7-8645000102C1865DX

Shan, Z., G. Shu, K. Li, X. Zhang, H. Wang, X. Cao, H. Jiang, and H. Weng, 2017Effect of hydrogenation of liquified heavy oil on direct coal liquification: Fuel, v. 194, p. 291-296.

https://doi.org/10.1016/i.fuel.2017.01.034

Smith, P. V. Jr., 1952a, Preliminary note on the origin of oil: American Association of Petroleum Geologists Bulletin, v. 36, p. 411-413.

https://doi.org/10.1306/3D93440C-16B1-11D7-8645000102C1865D

Smith, P.V. Jr., 1952b, The origin of hydrocarbons in recent sediments from the Gulf of Mexico: Science, v. 116, p. 437-439. https://www.jstor.org/stable/1680149

Smith, P. V. Jr., 1954, Studies on origin of petroleum: Occurrence of hydrocarbons in recent sediments: American Association of Petroleum Geologists Bulletin, v. 38, p. 377-404.

https://doi.org/10.1306/5CEADEE7-16BB-11D7-8645000102C1865D

Spacapan, J. B., J. O. Palma, O. Galland, R. E. Manceda, E. Rocha, A. D'Odorico, and H. A. Leanza, 2018, Thermal impact of igneous sill-complexes on organic-rich formations and implications for 
petroleum systems: A case study in the northern Neuquén Basin Argentina: Marine and Petroleum geology, v. 91, p. 519-531. https://doi.org/10.1016/j.marpetgeo.2018.01.018

Strauss, O. P., K. N. Jha., D. S. Montgomery, 1977, Chemical Composition of gases in Athabasca bitumen and low-temperature thermolysis of oil sand, asphaltene and maltene: Fuel, v. 56, . 114 120. https://doi.org/10.1016/0016-2361(77)90128-4

Teas, L. P., and C. R. Miller, 1933, Raccoon Bend Oil Field Austin County, Texas, American Association of Petroleum Geologist Bulletin, v .17, p. 1459-1491. https://doi.org/10.1306/3D932BD8-16B1-11D7$\underline{8645000102 C 1865 \mathrm{D}}$

Tissot, B. P., and D. H. Welte, 1978, Petroleum Formation and Occurrence, 1s ed., Springer-Verlag New York Heidelberg Berlin, $538 \mathrm{p}$.

Tissot, B. P. and D. H. Welte, 1984, Petroleum Formation and Occurrence, 2nd ed., Springer-Verlag New York Heidelberg Berlin, 699 p.

Tissot, B. Y. Califet-Debyser, G. Deroo, and J. L. Oudin, 1971, Origin and Evolution of Hydrocarbons in Early Toarcian Shales, Paris Basin, France, American Association of Petroleum Geologists Bulletin, v. 55, p. 2177-2193.

https://doi.org/10.1306/819A3E2E-16C5-11D7-8645000102C1865D

Tissot, B., B. Durand, J. Espitalié, and A. Combaz, 1974, Influence of nature and diagenesis of Organic matter in formation of petroleum, American Association of Petroleum Geologists Bulletin. v. 58, p. 499-506.

https://doi.org/10.1306/83D91425-16C7-11D7-8645000102C1865D

Van Tuyl , F. M., and B. H Parker, 1941, The Time of Origin and Accumulation of Petroleum: Colorado School Mines Quaternary, v. 36, 180 p.

Waples, D. W., 2000, The kinetics of in-reservoir oil destruction and gas formation: constraints from experimental and empirical data, and from thermodynamics: Organic Geochemistry, v. 31, pp. 553575. https://doi.org/10.1016/S0146-6380(00)00023-1

Weeks, L. G. 1958, Habitat of oil and some factors that controls it: In Weeks, L. G. eEd., Habitat of oil: The American Association of Petroleum Geologists Bulletin, p. 1-61.

https://archives.datapages.com/data/specpubs/basinar2/data/a125/a125/0001/0000/0001.htm Wiebe, R., and V. L. Gaddy, 1934 Solubility of hydrogen in water at 0, 50, 75 and $100^{\circ} \mathrm{C}$ from 25 to 
1000 atmospheres: , Journal of American Society, v.55. p. 947-953.

https://pubs.acs.org/doi/pdf/10.1021/ja01316a022

Wilhelms, A, and S. R. Later, 1994. On the origin of tar mats in petroleum reservoirs: Part II: Formation mechanisms for tar mats: Marine and Petroleum Geology, v. 11, p. 442-456. https://doi.org/10.1016/0264-8172(94)90078-7

Wilson, H. H., 1990, The case of early generation and accumulation of oil: Journal of Petroleum Geology, v. 13, p. 127-156. https://doi.org/10.1111/j.1747-5457.1990.tb00836.x

Wilsons, H. H., 2005, A review of geological data that conflict with the paradigm of catagenic generation and migration of oil: Journal of Petroleum Geology, v. 28, p 287-300.

https://doi.org/10.1111/j.1747-5457.2005.tb00084.x

Zgonnik, V., 2020, The Occurrence and geoscience of natural hydrogen: A comprehensive review: Earth-Science Reviews, v. 203, p. 1-51. https://doi.org/10.1016/i.earscirev.2020.103140

Zhang, T., Huang, S. Luo, P., 2010, Coupling immiscible $\mathrm{CO}_{2}$ technology and polymer injection to maximize EOR performance for heavy oils: Journal of Canadian Petroleum Geology, v. 49. p. 27-33. https://doi.org/10.2118/137048-PA

Zhao, B., and J. M. Shaw, 2007, Composition and size distribution of coherent nanostructures in Athabasca bitumen and Maya Crude oil: Energy \& Fuels, v. 21. p. 2795-2804.

https://pubs.acs.org/doi/abs/10.1021/ef070119u

Zhu, G. A. V. Milkov, F. Chen, N. Weng, Z. Zhang, H. Yang, K. Liu, Y. Zhu, 2018 Non-cracked oil in ultradeep high-temperature reservoirs in the Tarim basin, China: Marine and Petroleum Geology, v. 89, p. 252-262. https://doi.org/10.1016/j.marpetgeo.2017.07.019 
